\title{
Ageing and smoking contribute to plasma surfactant proteins and protease imbalance with correlations to airway obstruction
}

\author{
Helen llumets ${ }^{1 *}$, Witold Mazur ${ }^{1}$, Tuula Toljamo², Noora Louhelainen ${ }^{1}$, Pentti Nieminen ${ }^{3}$, Hideo Kobayashi ${ }^{4}$, \\ Nobuhisa Ishikawa ${ }^{1,5}$ and Vuokko L Kinnula ${ }^{1}$
}

\begin{abstract}
Background: A significant number of young people start smoking at an age of 13-15, which means that serious smoking-evoked changes may have been occurred by their twenties. Surfactant proteins (SP) and matrix metalloproteinases (MMPs) and their tissue inhibitors (TIMPs) have been linked to cigarette smoke induced lung remodelling and chronic obstructive pulmonary disease (COPD). However, the level of these proteins has not been examined during ageing or in young individuals with short smoking histories.
\end{abstract}

Methods: Plasma levels of SP-A, SP-D, MMP-9, and TIMP-1 were measured by EIA/ELISA from young (18-23 years) non-smoking controls (YNS) $(n=36)$, smokers (YS) $(n=51)$, middle aged/elderly (37-77 years) non-smoking controls (ONS) ( $n=40)$, smokers (OS) $(n=64)$ (FEV1/FVC $>0.7$ in all subjects) and patients with COPD $(n=44$, 35-79 years).

Results: Plasma levels of SP-A increased with age and in the older group in relation to smoking and COPD. Plasma SP-D and MMP-9 levels did not change with age but were elevated in OS and COPD as compared to ONS. The TIMP-1 level declined with age but increased in chronic smokers when compared to ONS. The clearest correlations could be detected between plasma SP-A vs. age, pack years and FEV1/FVC. The receiver operating characteristic (ROC) curve analysis revealed SP-A to be the best marker for discriminating between patients with COPD and the controls (area under ROC curve of 0.842; 95\% confidence interval, 0.785-0.899; $p<0.001$ ).

Conclusions: Age has a significant contribution to potential markers related to smoking and COPD; SP-A seems to be the best factor in differentiating COPD from the controls.

\section{Background}

Smoking is the major risk factor for the development of chronic obstructive pulmonary disease (COPD), and smoking cessation is the only effective way to slow down disease progression [1-3]. Young people generally start smoking at 13-15 years of age, which means that significant changes due to smoking may have been occurred within 10 years i.e. by the time they are 25 years, they may have suffered the damage which will later develop into COPD. There is a need to devise sensitive and specific markers for early COPD, but at

\footnotetext{
* Correspondence: helen.lumets@helsinki.fi

'Department of Medicine, Division of Pulmonary Medicine, University of

Helsinki and Helsinki University Central Hospital, Helsinki, Finland

Full list of author information is available at the end of the article
}

present, the tests are unreliable. In this study, we measured plasma levels of surfactant protein A (SP-A), surfactant protein D (SP-D), matrix metalloproteinase-9 (MMP-9) and tissue inhibitor of matrix metalloproteinase-1 (TIMP-1) in young and middle aged/elderly smokers and in patients with COPD. The selection of these potential marker compounds was based on previous studies on COPD, i.e. either non-hypothesis/proteomics (SP-A) or hypothesis driven (SP-D, MMP-9) studies, which have indicated that especially these markers may predict COPD, its development and/or progression [4-9]. These compounds have never been compared previously in one single investigation.

Pulmonary surfactant is a mixture of phospholipids and proteins formed mainly by type II pneumocytes 
[10]. SP-A and SP-D are members of the collectin family and play important and unique roles in pulmonary defense against inflammation/oxidative stress [11,12]. The surfactant composition and functions have been found to be modulated by smoking and/or COPD [13-16], and most studies in this field have reported elevated levels of SP-A in the serum of the patients with COPD $[6,8]$. Serum SP-D has been postulated to be a potential marker for COPD, being able to predict both exacerbations and response to corticosteroid therapy [17-20]. Surfactants have also been found to regulate the balance of proteases/antiproteases through different pathways, SP-A may even regulate MMP-9 production and function [21-24]. One of the most widely suggested hypothesis in the pathogenesis of COPD involves an imbalance between proteases and antiproteases $[4,25]$.

Matrix metalloproteinases cleave components of the extracellular matrix and basement membranes and the balance of their activities is strictly controlled by their inhibitors. The changes in these proteases, especially MMP-9 and its major endogenous inhibitor TIMP-1, have been strongly linked to smoking and COPD $[4,5,26,27]$. However, little is known about whether there are age related alterations in these proteins in smokers and/or COPD.

The main goal of this study was to find out whether smoking and ageing affect the levels and relationships between circulating SP-A, SP-D, MMP-9 and TIMP-1.

The second purpose was to determine whether the levels of these markers would be associated with demographic parameters and lung function values in young and middle aged/elderly smokers, as well as in COPD patients in comparison to their age-matched controls. None of the subjects had any other environmental exposures, all COPD cases were newly diagnosed, and had no other diagnosed diseases nor were they taking any medications.

\section{Methods}

\section{Subjects and samples}

Plasma samples were collected from middle aged/elderly subjects who had been contacted from the Division of Pulmonary Medicine, Lapland Central Hospital [28] and from young smokers and non-smokers who were military draftees from the Northern Command of the Finnish Defence Forces [29]. Details of these cohorts have been described in the abovementioned studies [28,29]. Based on self-reported detailed questionnaire all subjects were symptom-free and considered themselves as healthy, they had no other environmental exposures (such as second hand smoke, pollutants or asbestos fibres) [28]. The study population included young (age < 25 years) healthy smokers (YS), young non-smoking healthy controls (YNS), middle-aged/elderly healthy smokers (OS) and non-smoking healthy controls (ONS), and patients with stable COPD (Stage I-III). The diagnosis of COPD was defined according to the Global Strategy for the diagnosis, management and prevention of COPD (GOLD) criteria; $\mathrm{FEV}_{1}<80 \%$ of predicted, $\mathrm{FEV}_{1} /$ FVC $<70 \%$ and bronchodilatation effect $<12 \%[2,30]$. Spirometric values were assessed by standard spirometry (Medriko M 904, Kuopio, Finland) and the Finnish reference values for spirometry [31]. Exclusion criteria included allergies, asthma, a history of respiratory disease, or respiratory infection less than 8 weeks before entering the study. None of the subjects had any other diagnosed disease or any medications. The study was approved by the Ethics Committee of Lapland Central Hospital (4th $4^{\text {th }}$ June 2003 and $31^{\text {st }}$ October 2006) and all participants provided written informed consent.

\section{The measurement of SP-A, SP-D, MMP-9 and TIMP-1}

Plasma samples were randomly chosen from the cohorts that represented the various sub-groups for the study. SP-A and SP-D levels were measured by commercially available EIA/ELISA kits (SP-A test Kokusai-F kit, Sysmex, Kobe, Japan; SP-D kit Yamasa EIA kit, Yamasa Co., Chiba, Japan) as described [6,32]. MMP-9 and TIMP-1 levels were determined by commercially available ELISA kits (Amersham Biosciences, Cardiff, UK) according to the manufacturers' instructions. The detection limits of SP-A and SP-D were $1.0 \mathrm{ng} / \mathrm{ml}$ and 17.2 $\mathrm{ng} / \mathrm{ml}$, respectively and for MMP-9 and TIMP-1 $0.6 \mathrm{ng} /$ $\mathrm{ml}$ and $1.25 \mathrm{ng} / \mathrm{ml}$, respectively.

\section{Statistical analysis}

The data are given as means together with standard deviation (SD). All statistical analyses were performed with the SPSS 18.0 software program (SPSS Inc., Chicago, IL). The analyses of variance (ANOVA) and t-test for independent groups were used to evaluate the statistical significances between the study groups. Linear multivariate regression analysis was used to study the independent effect of age, smoking status and COPD to SP-A, SP-D, MMP-9 and TIMP-1. Correlations between the variables were determined with the Pearson correlation coefficient. Due to the pair wise comparisons, a p-value of $<0.01$ was considered statistically significant. SP-A, SP-D, MMP-9 and TIMP-1 levels were further analyzed for their predictive capability to distinguish patients with COPD from the control subjects (YNS and ONS) according to receiver operating characteristic (ROC) curves.

\section{Results}

\section{Subjects and lung function characteristics}

The characteristics of the subjects are shown in Table 1. All young and middle aged/elderly smokers and non- 
Table 1 The characteristics of the patients

\begin{tabular}{|c|c|c|c|c|c|}
\hline \multirow[t]{2}{*}{ Variable } & \multicolumn{2}{|c|}{ Young } & \multicolumn{3}{|c|}{ Middle aged/elderly } \\
\hline & Non-smokers & Smokers & Non-smokers & Smokers & COPD \\
\hline Number & 36 & 51 & 40 & 64 & 44 \\
\hline Age (yr) & $19.5(0.8)$ & $20.0(1.0)$ & $53.3(8.8)$ & $52.1(8.0)$ & $61.3(8.5)$ \\
\hline Sex (F/M) & $2 / 34$ & $1 / 50$ & $28 / 12$ & $24 / 40$ & $9 / 35$ \\
\hline Pack-years & - & $5.1(2.3)$ & - & $30.4(14.3)$ & $39.8(15.0)$ \\
\hline BMI & $24.1(2.5)$ & $24.1(3.1)$ & $26.5(4.2)$ & $27.7(4.0)$ & $26.9(3.8)$ \\
\hline $\begin{array}{l}\text { Post- bronchodilator } \\
\text { FVC (I) }\end{array}$ & $5.5(0.8)$ & $5.5(0.8)$ & $3.8(0.8)$ & $4.0(0.9)$ & $3.8(0.9)$ \\
\hline FEV1 (I) & $4.8(0.7)$ & $4.8(0.7)$ & $3.2(0.6)$ & $3.3(0.7)$ & $2.3(0.7)$ \\
\hline $\begin{array}{l}\text { FEV1 } \\
\text { (\% predicted) }\end{array}$ & $97.3(6.1)$ & $100.1(9.5)$ & $104.7(13.6)$ & $95.3(12.2)$ & $70.0(16.8)$ \\
\hline FEV1/FVC & $87.6(5.6)$ & $87.1(4.8)$ & $84.5(5.9)$ & $82.7(5.1)$ & $60.6(9.3)$ \\
\hline
\end{tabular}

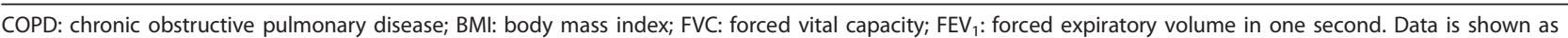
mean (SD).

smokers had normal airway function according to the GOLD criteria (post bronchodilator $\mathrm{FEV}_{1} / \mathrm{FVC}>0.7$ ) [30]. In the COPD group, there were 15 patients with stage I, 24 patients with stage II and 5 patients with stage III COPD according to the GOLD classification. All COPD cases were newly diagnosed and were taking no regular medications.

\section{The level of SP-A increases with ageing, smoking, and COPD}

Plasma level of SP-A increased with age in non-smokers and smokers $(\mathrm{p}<0.0001$ and $\mathrm{p}<0.0001)$, respectively. In young non-smokers (YNS), the mean values were $22.2 \pm 6.0 \mathrm{ng} / \mathrm{ml}$, and in middle aged/elderly non-smokers they were $31.4 \pm 10.6 \mathrm{ng} / \mathrm{ml}$, the corresponding mean values in YS being $23.0 \pm 6.8 \mathrm{ng} / \mathrm{ml}$ and OS 43.3 $\pm 17.5 \mathrm{ng} / \mathrm{ml}$. This latter finding may be partly related to the longer smoking history of OS. Cigarette smoke had no significant effect on the SP-A levels in the young age group, with their relatively short smoking histories. In the older age group, plasma SP-A was higher in OS when compared to ONS ( $\mathrm{p}<0.0001$ ). Importantly, plasma SP-A was also higher in COPD $(55.4 \pm 24.6 \mathrm{ng} /$ $\mathrm{ml})$ compared to OS ( $\mathrm{p}=0.009)$, and ONS ( $<<0.0001)$ (Figure 1A). The linear regression analysis confirmed that age (regression coefficient $(B)=6.01$, standard error $(\mathrm{SE})=2.54, \mathrm{p}=0.019)$, cigarette smoking $(\mathrm{B}=$ $0.45, \mathrm{SE}=0.07, \mathrm{p}<0.001)$ and $\mathrm{COPD}(\mathrm{B}=17.08, \mathrm{SE}=$ $3.67, \mathrm{p}<0.001)$ had independent effects on SP-A level.

The level of SP-D does not change with ageing but is elevated in OS and COPD compared to ONS

Plasma level of SP-D did not change with age, i.e. the mean levels in YNS and ONS $(109.0 \pm 62.3 \mathrm{ng} / \mathrm{ml}$ and $106.0 \pm 41.2 \mathrm{ng} / \mathrm{ml}$ ) were similar. Furthermore there was no difference between YNS and YS. In the older group, the levels were higher in OS $(156.2 \pm 90.2 \mathrm{ng} / \mathrm{ml})$ and COPD $(186.3 \pm 101.9 \mathrm{ng} / \mathrm{ml})$ when compared to ONS ( $\mathrm{p}=0.012$ and $\mathrm{p}<0.0001$ ) but there was no significant difference between OS and COPD (Figure 1B). COPD patients had even higher levels of SP-D ( $\mathrm{B}=$ $64.72, \mathrm{SE}=19.53, \mathrm{p}=0.001)$ when adjusted for age with linear multivariate regression analysis.

\section{The level of MMP-9 is elevated in OS and COPD compared to ONS}

The plasma concentrations of MMP-9 were very similar in YNS and ONS $(47.1 \pm 49.1$ and $44.4 \pm 34.6 \mathrm{ng} / \mathrm{ml})$ and there was no significant difference between YNS and YS. In the older age group, the levels were higher in OS $(86.5 \pm 40.8 \mathrm{ng} / \mathrm{ml})$ compared to ONS ( $\mathrm{p}<0.0001)$. The level of MMP-9 was significantly higher in COPD than in ONS ( $p=0.033$ ). The MMP-9 results are summarized in Figure $1 \mathrm{C}$. Linear regression analysis revealed that both age $(\mathrm{B}=0.44, \mathrm{SE}=0.19, \mathrm{p}=0.022)$ and cigarette smoking $(B=26.0, S E=6.91, p<0.0001)$ had independent effects on the MMP-9 level.

\section{The levels of TIMP-1 and MMP-9/TIMP-1 increase in response to long-term smoking}

The plasma level of TIMP-1 declined with age ( $\mathrm{p}=$ 0.03 ), but there was no significant difference between YNS and YS. In the older group, the TIMP-1 levels were higher in OS $(117.7 \pm 18.2 \mathrm{ng} / \mathrm{ml})$ and COPD $(114.9 \pm 23.5 \mathrm{ng} / \mathrm{ml})$ than in ONS $(81.3 \pm 26.6 \mathrm{ng} / \mathrm{ml}, \mathrm{p}$ $<0.001$ and $\mathrm{p}=0.001)$, but there was no significant difference between OS and COPD (Figure 1D). The ratio of MMP-9 to TIMP-1 did not change with age. In addition, there were no significant differences between YNS and YS. In the older group, the MMP-9/TIMP-1 ratio was higher in OS $(0.79 \pm 0.3)$ than in ONS $(0.28 \pm 0.2$, $\mathrm{p}<0.0001)$ indicative of a significant protease/antiprotease imbalance in favor of proteases. In addition, the linear regression analysis confirmed the independent 


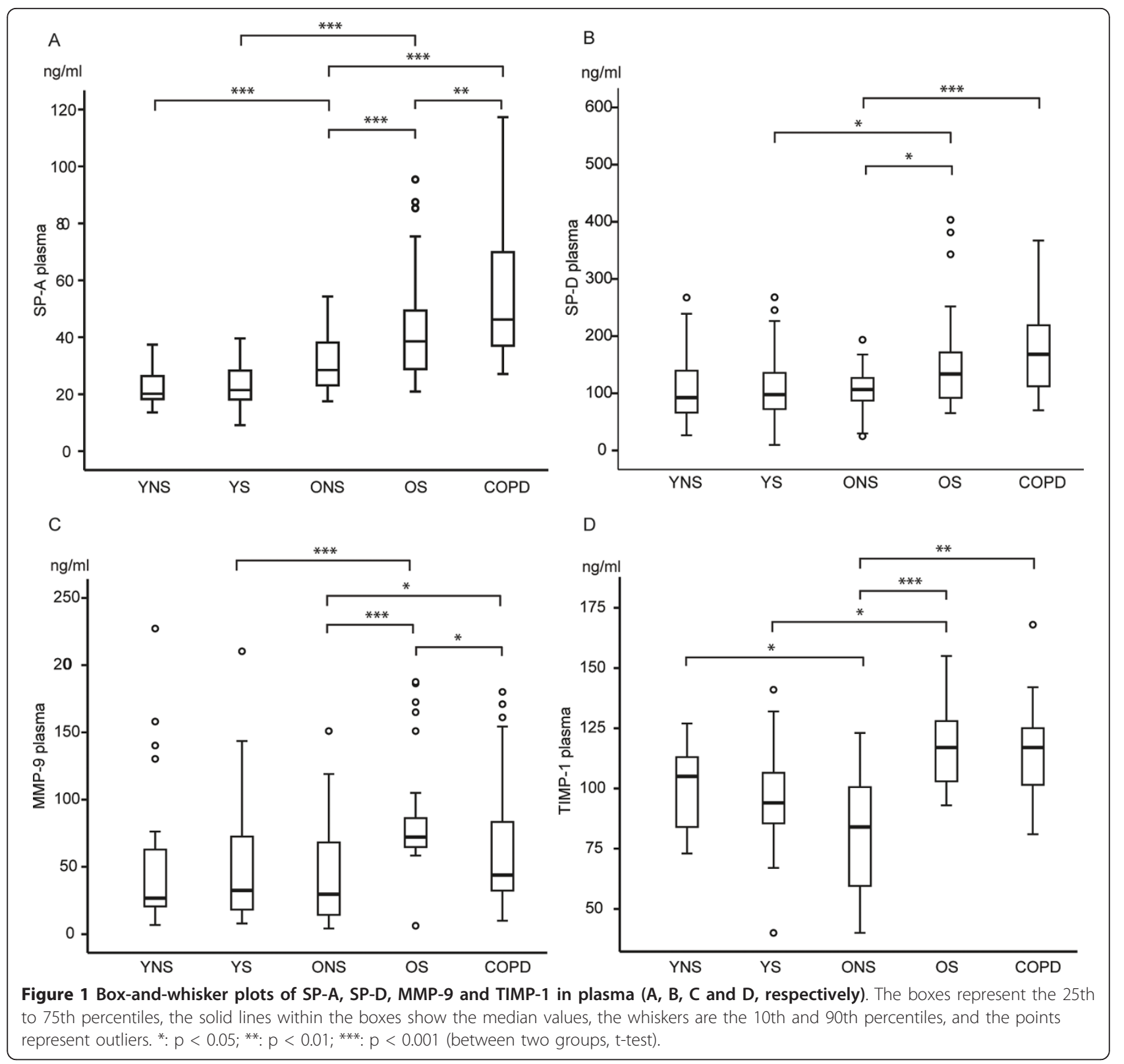

effect of smoking on TIMP-1 $(\mathrm{B}=16.18, \mathrm{SE}=6.66, \mathrm{p}=$ $0.018)$ and MMP-9/TIMP-1 $(\mathrm{B}=4.01, \mathrm{SE}=0.15, \mathrm{p}=$ $0.014)$.

\section{Significant correlations can be seen especially with SP-A}

Figures 2, 3 and 4 show how SP-A, SP-D and MMP-9 are related to age, pack years, BMI and lung functions in different study groups. The clearest correlations could be seen with plasma SP-A vs. age, pack years and FEV1/FVC (Figure 2A-D), though some correlations could also be observed with SP-D (Figure 3A-D). The plasma MMP-9 level correlated only with age and pack years, though some minor correlations could be seen with all these parameters and BMI (Figure 4A-D).
The levels of SP-A also correlated with SP-D ( $r=0.36$, $\mathrm{p}<0.0001)$.

\section{Receiver Operating Characteristic (ROC) curve analysis is} most accurate for SP-A

ROC curve analysis was carried out to evaluate the sensitivity, specificity and diagnostic accuracy of plasma SP-A, SP-D, MMP-9 and TIMP-1. The areas under the ROC curve were as follows: for SP-A: 0.845 (95\% confidence interval (CI), 0.787 to $0.902, \mathrm{p}<0.001$ ); for SP-D: 0.734 (95\% CI, 0.636 to $0.883, \mathrm{p}<0.001$ ); for MMP-9: 0.551 (95\% CI, 0.450 to $0.652, \mathrm{p}=0.320$ ) and for TIMP-1: 0.664 (95\% CI, 0.516 to $0.813, \mathrm{p}=0.051$ ) (Figure 5). 


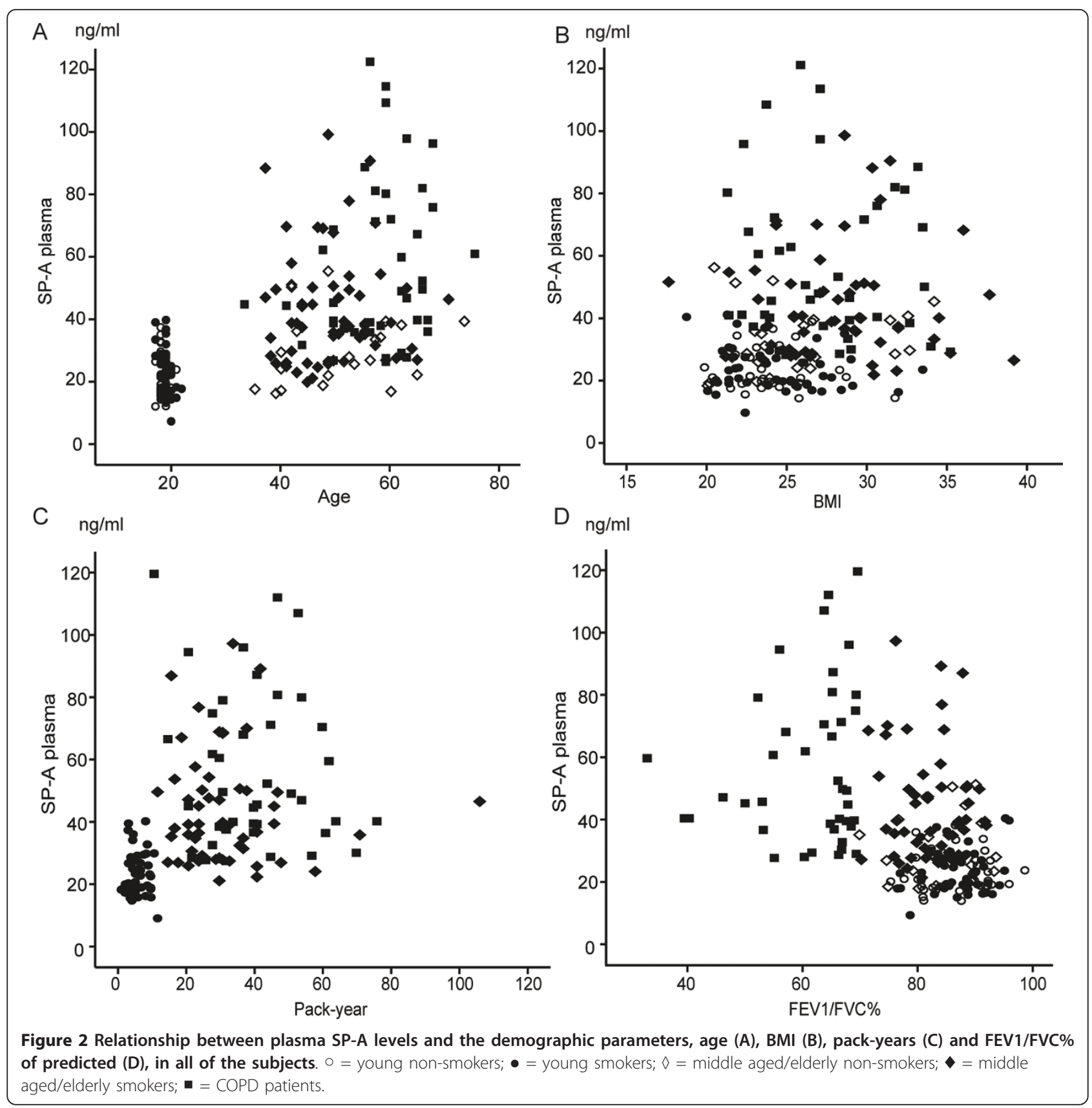

\section{Discussion}

The present study evaluated plasma levels of SP-A, SPD, MMP-9 and TIMP-1 in young and middle aged/ elderly non-smokers and smokers, and patients with COPD. All of these putative markers have been suggested to associate with COPD. When these potential parameters were evaluated, SP-A appeared to be the most promising marker for COPD since its levels were elevated after long-term smoking and also in COPD as compared to the situation in chronic smokers. SP-A was also clearly correlated with age, pack years and airway obstruction. However, it remains unclear whether SP-A can be used as a marker for COPD or its development. The levels of none of these proteins were changed due to smoking in the group of young smokers who had relatively short smoking histories, no diseases or other exposures and normal values in spirometry.

The elevation of plasma SP-A by smoking/COPD is in agreement with previous investigations though there are many controversial findings as well. Plasma/serum SP-A levels have been reported to be elevated in COPD in a Japanese cohort of smokers and patients with COPD 


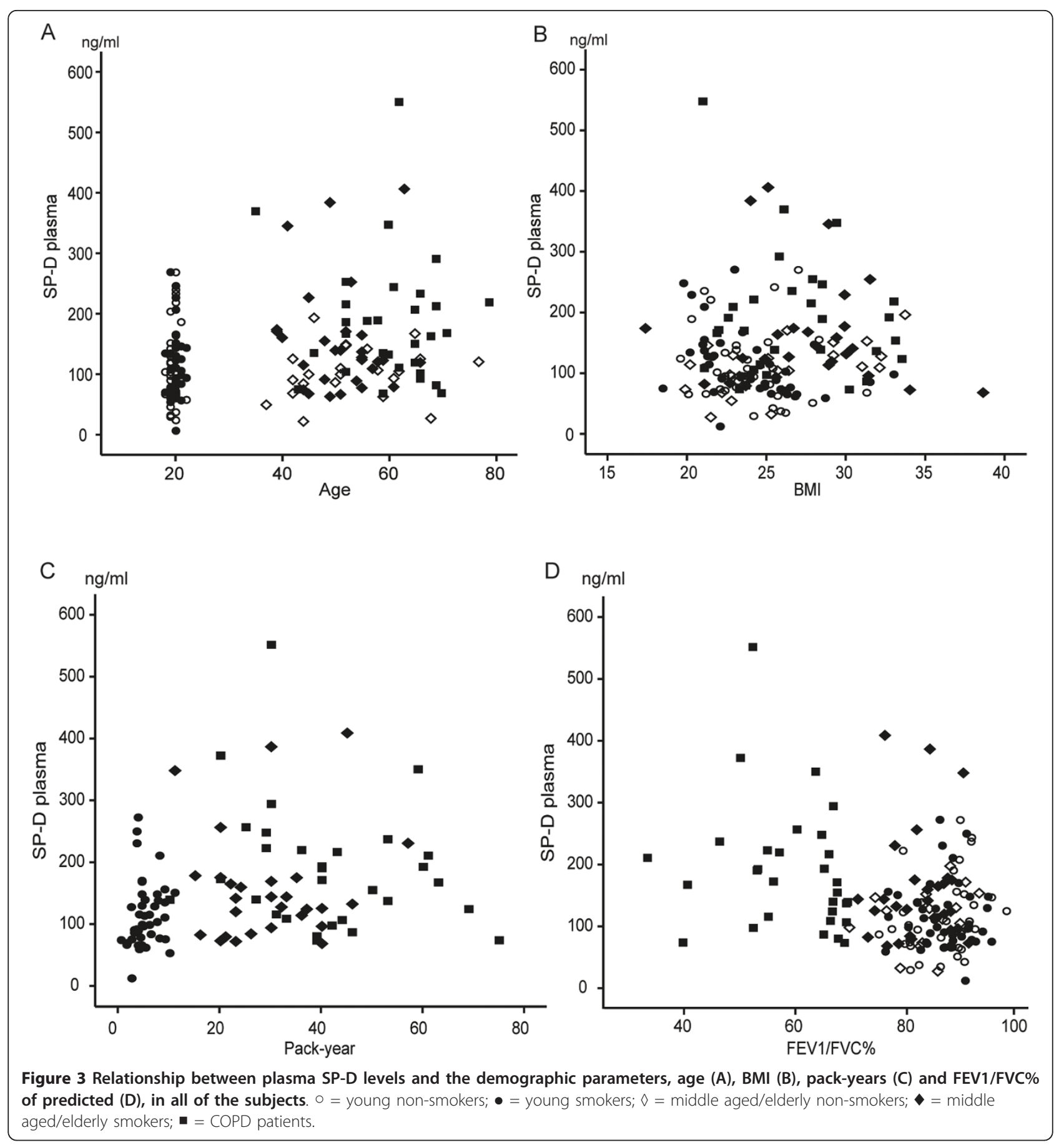

and pulmonary thromboembolism [6]. These findings are in line with other investigations of the levels of SP$\mathrm{A}$ in the circulating blood [33-36]. In a recent proteomic study of pulmonary tissue, SP-A was found to be one of the most markedly elevated spots when investigated by two dimensional electrophoresis, i.e. its presence in the spots was confirmed by mass spectrometry [8]. There are some opposite findings with respect to the circulating SP-A levels in smokers and/or COPD determined in serum [20,37], lung tissue [38] or bronchoalveolar lavage (BAL) $[15,16,39]$. In some of those studies, SP-A had been either investigated by a non-quantitative immunohistochemical technique or from BAL, which is problematic due to its invasive nature and collapse of the airways in COPD. Very few studies have investigated the effect of age on the levels of potential plasma biomarkers, this report has concentrated on these changes, especially with respect to SP-A, since these may be 


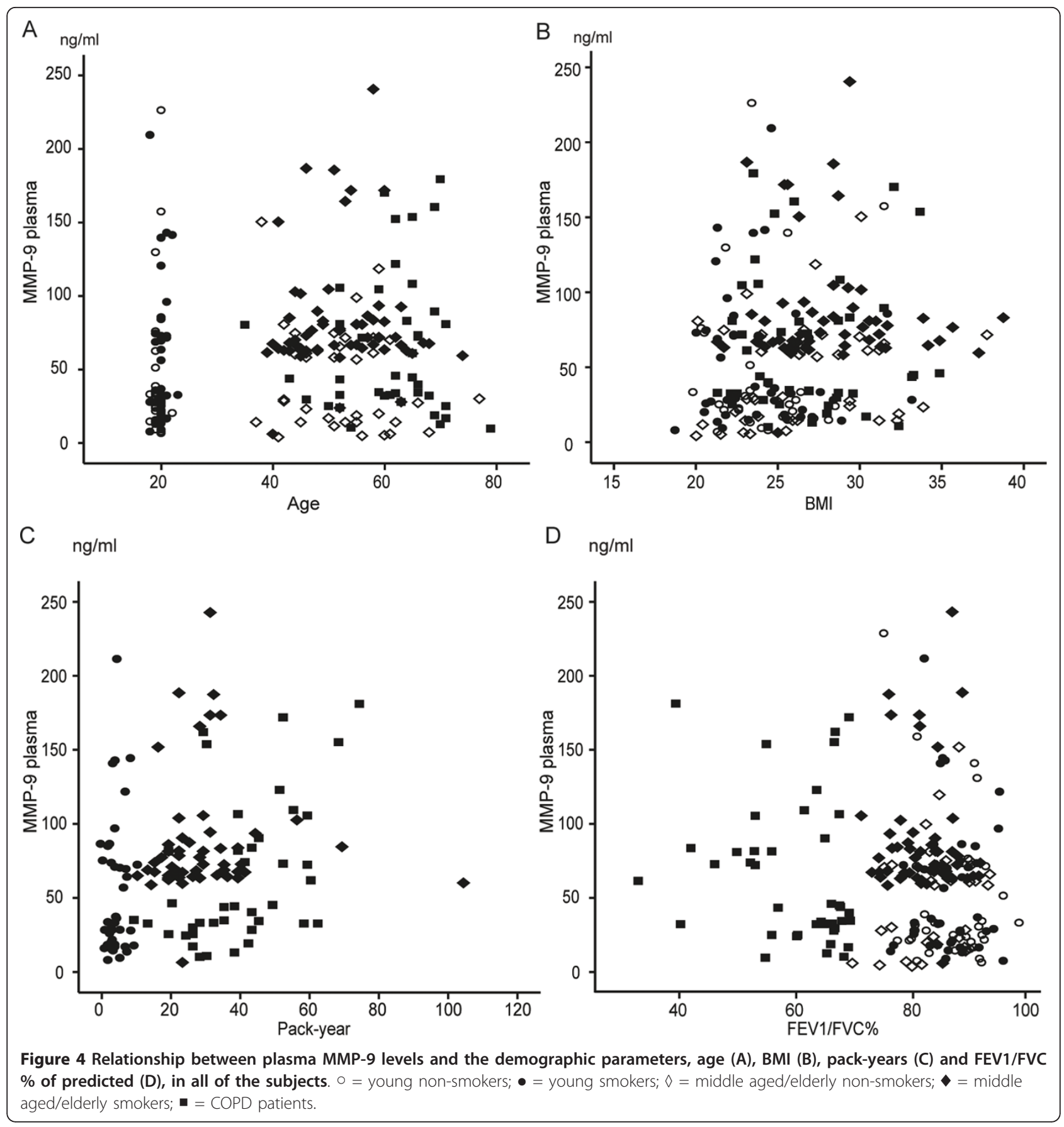

remarkable and need to be taken into careful consideration in all corresponding investigations.

Genotype and age of the patients have been shown to have an influence on the SP-A levels $[40,41]$ and some SP-A alleles may increase the risk for development of COPD [42]. In the study of Ohlmeier [8], SP-A was confirmed to represent SP-A2, but the assay used in the present study is known to detect both SP-A1 and SP-A2 isoforms. Further studies will be necessary to investigate the long term changes in plasma SP-A levels, and also if
SP-A1 and SP-A2 predict disease progression or whether these changes are related to smoking alone.

SP-D has been proposed to represent a marker for COPD, especially predicting its exacerbations [17]. However, there are studies indicating that serum SP-D is not changed [6] in smokers/COPD or that its levels in BAL are reduced in smokers $[15,16,43]$ and patients with COPD [44]. In the present study, plasma SP-D levels did not differ between the young and old age groups; neither were they different between OS and COPD. 


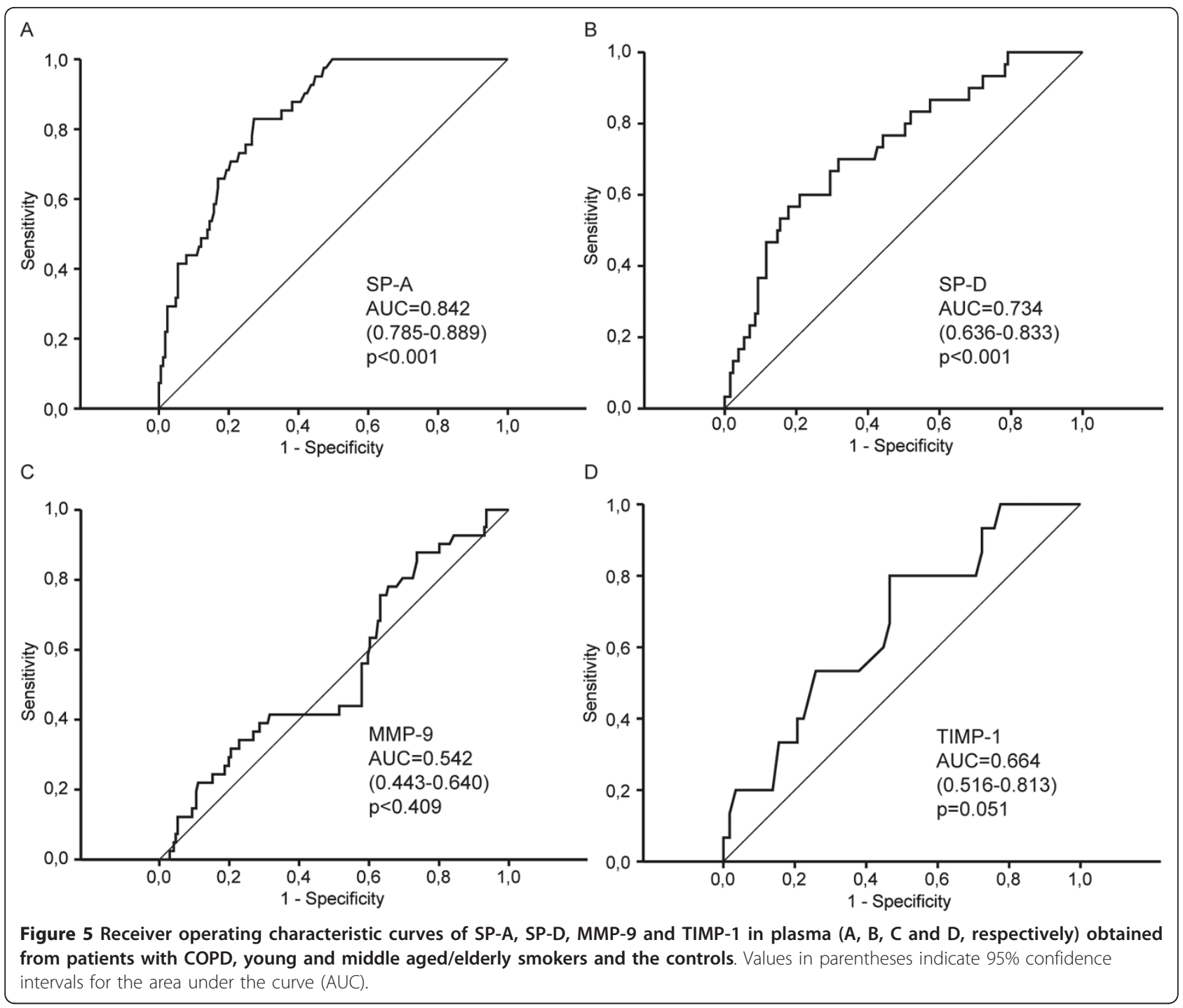

These data are in agreement with our earlier results showing no significant changes in lung tissue SP-D in COPD [8]. Overall, SP-D revealed only slight variability, possibly some elevation due to smoking, but the changes were smaller than those observed with SP-A.

MMP-9 and TIMP-1 have been postulated to be associated with COPD and its development $[4,5,26,27]$. This was the reason why MMP-9 and TIMP-1 were included in the present study. This study confirms previous investigations that the MMP-9 level is increased in long-term smokers $[5,45]$, but as far as we are aware, there are no studies which have investigated the levels of MMP-9 or TIMP-1 in different age groups of nonsmokers or smokers. This study detected no significant difference in plasma MMP-9 between YNS and YS but as shown earlier, the changes observed in MMP-9 and TIMP-1 were mostly attributable to smoking. These data also suggest that short-term smoking ( $<10$ years) in young healthy subjects does not significantly modify the levels of circulating MMP-9 or TIMP-1. However, longterm smoking ( $>10$ years) increased both plasma levels of MMP-9 and MMP-9/TIMP-1, perhaps reflecting increased systemic inflammation, though active remodelling in the airways is evidently more prominent. Since there are multiple MMPs and TIMPs, the MMP9/TIMP-1 ratio alone does not reflect the overall protease/antiprotease balance in the lung. Many studies have been conducted on MMPs and the protease/antiprotease balance in COPD, but it is still unclear if these changes predict COPD in the longitudinal setting.

The weakness of this study is that in the young age group, most of the individuals were men. Therefore we compared the results between the genders in the middle aged/elderly group but could detect no significant differences between the genders with respect to the levels of SP-D, MMP-9 or TIMP-1. Only the plasma SP-A level 
was significantly higher in middle-aged/older non-smoking women when compared to the men $(\mathrm{p}=0.012)$. This was also a cross-sectional study, and therefore the value of these proteins in COPD will require further prospective investigations. This study has significant strengths i.e. none of the non-smokers or smokers had any other exposures. The chronic smokers suffering from COPD, were taking no medications for COPD since they had newly diagnosed COPD and none of them had any other diseases or were taking any medications. This does not exclude the existence of cardiovascular or other organ involvements, though all subjects considered themselves as healthy [28].

\section{Conclusions}

In conclusion, the plasma level of SP-A may be a promising marker for COPD, it displayed age related changes and exhibited a significant elevation due to smoking, but prospective studies will be needed to elucidate the significance of SP-A and also potential new markers of COPD. Two prospective studies are ongoing in our laboratory $[28,46]$, where potential markers are being evaluated and will be tested within the next two and five years. These and other potential markers may also prove to be important in young smokers, especially when evaluating early lung damage in cases when smoking or other environmental exposures are combined with impaired lung development and/or other abnormalities of the lung.

\section{List of abbreviations}

B: regression coefficient; BMl: body mass index; Cl: confidence interval; COPD: chronic obstructive pulmonary disease; EIA: enzyme immunoassay; ELISA: enzyme-linked immunosorbent assay; FEV1: forced expiratory volume in one second; FVC: forced vital capacity; GOLD: the Global initiative for chronic Obstructive Lung Disease; MMP: matrix metalloproteinase; ONS: middle aged/elderly (old) non-smokers; OS: middle aged/elderly (old) smokers; ROC: receiver operating characteristic; TIMP: tissue inhibitor of metalloproteinase; SD: standard deviation; SE: standard error; SP: surfactant protein; YNS: young non-smokers; YS: young smokers.

\section{Acknowledgements}

Tiina Marjomaa is acknowledged for her excellent technical assistance. This work was partly supported by the Finnish Antituberculosis Association Foundation, Yrjö Jahnsson Foundation, a special governmental subsidy for health sciences research (EVO) of Helsinki University Central Hospital and Lapland Central Hospital, the Research Program for the Intelligent Monitoring Health and Well-being (Tekes IMO), and Grants-in-Aid for Scientific Research from the Ministry of Education, Culture, Sports, Science and Technology of Japan.

\section{Author details}

${ }^{1}$ Department of Medicine, Division of Pulmonary Medicine, University of Helsinki and Helsinki University Central Hospital, Helsinki, Finland. ${ }^{2}$ Department of Medicine, Division of Pulmonary Medicine, Lapland Central Hospital, Rovaniemi, Finland. ${ }^{3}$ Medical informatics and statistics research group, University of Oulu, Oulu, Finland. ${ }^{4}$ Department of Medicine, Division of Pulmonary Medicine, National Defense Medical College, Tokorozawa, Japan. ${ }^{5}$ Departments of Molecular and Internal Medicine, Graduate School of Biomedical Science, Hiroshima University, Hiroshima, Japan.

\section{Authors' contributions}

$\mathrm{HI}$ participated in the planning of the study, performed part of the laboratory analysis, together with PN made statistical analyses and interpretation of data, prepared the tables, conducted the literature research and participated in the writing process. WM prepared the figures and participated in the writing process. TT participated in the recruitment and interview of the subjects and their characterization and was responsible for the lung function analysis. NL participated in the laboratory analysis and in the writing process. PN contributed to the statistical analyses and interpretation of data. HK was responsible for SP-A analysis and revision of the manuscript. $\mathrm{NI}$ calculated the ROC curves and prepared the figures. VK is the principal investigator, has designed the study, conducted the literature research and had a major role in writing process. All authors read and approved the final manuscript.

\section{Competing interests}

The authors declare that they have no competing interests.

Received: 29 October 2010 Accepted: 19 April 2011

Published: 19 April 2011

\section{References}

1. Fletcher C, Peto R: The natural history of chronic airflow obstruction. $\mathrm{Br}$ Med J 1977, 1:1645-1648

2. Rabe KF, Hurd S, Anzueto A, Barnes PJ, Buist SA, Calverley P, Fukuchi Y, Jenkins C, Rodriguez-Roisin R, van Weel C, Zielinski J: Global strategy for the diagnosis, management, and prevention of chronic obstructive pulmonary disease: GOLD executive summary. Am J Respir Crit Care Med 2007, 176:532-555

3. Scanlon PD, Connett JE, Waller LA, Altose MD, Bailey WC, Buist AS: Smoking cessation and lung function in mild-to-moderate chronic obstructive pulmonary disease. The Lung Health Study. Am J Respir Crit Care Med 2000, 161:381-390.

4. Beeh KM, Beier J, Kornmann O, Buhl R: Sputum matrix metalloproteinase9, tissue inhibitor of metalloprotinease-1, and their molar ratio in patients with chronic obstructive pulmonary disease, idiopathic pulmonary fibrosis and healthy subjects. Respir Med 2003, 97:634-639.

5. Ilumets $H$, Rytilä $P$, Demedts I, Brusselle GG, Sovijärvi A, Myllärniemi M, Sorsa T, Kinnula VL: Matrix metalloproteinases $-8,-9$ and -12 in smokers and patients with stage 0 COPD. Int J Chron Obstruct Pulmon Dis 2007, 2:369-379.

6. Kobayashi $H$, Kanoh S, Motoyoshi K: Serum surfactant protein-A, but not surfactant protein-D or KL-6, can predict preclinical lung damage induced by smoking. Biomarkers 2008, 13:385-392.

7. Louhelainen N, Stark H, Mazur W, Rytilä P, Djukanovic R, Kinnula VL: Elevation of sputum matrix metalloproteinase- 9 persists up to 6 months after smoking cessation: a research study. BMC Pulm Med 2010, 10:13.

8. Ohlmeier S, Vuolanto M, Toljamo T, Vuopala K, Salmenkivi K, Myllärniemi M, Kinnula VL: Proteomics of human lung tissue identifies surfactant protein A as a marker of chronic obstructive pulmonary disease. J Proteome Res 2008, 7:5125-5132

9. Sin DD, Leung R, Gan WQ, Man SP: Circulating surfactant protein D as a potential lung-specific biomarker of health outcomes in COPD: a pilot study. BMC Pulm Med 2007, 7:13.

10. Kishore U, Greenhough TJ, Waters P, Shrive AK, Ghai R, Kamran MF, Bernal AL, Reid KB, Madan T, Chakraborty T: Surfactant proteins SP-A and SP-D: structure, function and receptors. Mol Immunol 2006, 43:1293-1315.

11. Mason RJ, Greene K, Voelker DR: Surfactant protein A and surfactant protein D in health and disease. Am J Physiol 1998, 275:L1-13.

12. Whitsett JA: Surfactant proteins in innate host defense of the lung. Biol Neonate 2005, 88:175-180.

13. Otto-Verberne CJ, Ten Have-Opbroek AA, Franken C, Hermans J, Dijkman JH: Protective effect of pulmonary surfactant on elastaseinduced emphysema in mice. Eur Respir J 1992, 5:1223-1230.

14. Wirtz HR, Schmidt M: Acute influence of cigarette smoke on secretion of pulmonary surfactant in rat alveolar type II cells in culture. Eur Respir J 1996, 9:24-32.

15. Honda Y, Takahashi H, Kuroki Y, Akino T, Abe S: Decreased contents of surfactant proteins A and D in BAL fluids of healthy smokers. Chest 1996, 109:1006-1009. 
16. Betsuyaku T, Kuroki $Y$, Nagai $K$, Nasuhara $Y$, Nishimura M: Effects of ageing and smoking on SP-A and SP-D levels in bronchoalveolar lavage fluid. Eur Respir J 2004, 24:964-970.

17. Lomas DA, Silverman EK, Edwards LD, Locantore NW, Miller BE, Horstman DH, Tal-Singer R: Serum surfactant protein D is steroid sensitive and associated with exacerbations of COPD. Eur Respir J 2009, 34:95-102.

18. Antoniu SA: Inhaled corticosteroids in COPD: systemic effects of a local therapy? Expert Opin Pharmacother 2008, 9:3271-3273.

19. Sin DD, Man SF, Marciniuk DD, Ford G, FitzGerald M, Wong E, York E, Mainra RR, Ramesh W, Melenka LS, Wilde E, Cowie RL, Williams D, Gan WQ, Rousseau R: The effects of fluticasone with or without salmeterol on systemic biomarkers of inflammation in chronic obstructive pulmonary disease. Am J Respir Crit Care Med 2008, 177:1207-1214.

20. Mutti A, Corradi M, Goldoni M, Vettori MV, Bernard A, Apostoli P: Exhaled metallic elements and serum pneumoproteins in asymptomatic smokers and patients with COPD or asthma. Chest 2006, 129:1288-1297.

21. LeVine AM, Whitsett JA, Gwozdz JA, Richardson TR, Fisher JH, Burhans MS, Korfhagen TR: Distinct effects of surfactant protein A or D deficiency during bacterial infection on the lung. J Immunol 2000, 165:3934-3940.

22. Ramadas RA, Wu L, LeVine AM: Surfactant protein A enhances production of secretory leukoprotease inhibitor and protects it from cleavage by matrix metalloproteinases. J Immunol 2009, 182:1560-1567.

23. Vazquez de Lara LG, Umstead TM, Davis SE, Phelps DS: Surfactant protein A increases matrix metalloproteinase- 9 production by THP-1 cells. Am $J$ Physiol Lung Cell Mol Physiol 2003, 285:L899-L906.

24. Wert SE, Yoshida M, LeVine AM, Ikegami M, Jones T, Ross GF, Fisher JH, Korfhagen TR, Whitsett JA: Increased metalloproteinase activity, oxidant production, and emphysema in surfactant protein D gene-inactivated mice. Proc Natl Acad Sci USA 2000, 97:5972-5977.

25. Gadek JE, Pacht ER: The protease-antiprotease balance within the human lung: implications for the pathogenesis of emphysema. Lung 1990, 168(Suppl):552-564.

26. Barnes PJ: Genetics and pulmonary medicine. 9. Molecular genetics of chronic obstructive pulmonary disease. Thorax 1999, 54:245-252.

27. Nagase $H$, Visse R, Murphy G: Structure and function of matrix metalloproteinases and TIMPs. Cardiovasc Res 2006, 69:562-573.

28. Toljamo T, Kaukonen M, Nieminen P, Kinnula VL: Early detection of COPD combined with individualized counselling for smoking cessation: a twoyear prospective study. Scand J Prim Health Care 2010, 28:41-46.

29. Hamari A, Toljamo T, Nieminen P, Kinnula VL: High frequency of chronic cough and sputum production with lowered exercise capacity in young smokers. Ann Med 2010, 42:512-520.

30. GOLD: Global strategy for diagnosis, management and prevention. 2009 [http://www.goldcopd.com].

31. Viljanen AA, Halttunen PK, Kreus KE, Viljanen BC: Spirometric studies in non-smoking, healthy adults. Scand J Clin Lab Invest Suppl 1982, 159:5-20.

32. Takahashi H, Fujishima T, Koba H, Murakami S, Kurokawa K, Shibuya Y, Shiratori M, Kuroki Y, Abe S: Serum surfactant proteins A and D as prognostic factors in idiopathic pulmonary fibrosis and their relationship to disease extent. Am J Respir Crit Care Med 2000, 162:1109-1114.

33. Robin M, Dong P, Hermans C, Bernard A, Bersten AD, Doyle IR: Serum levels of CC16, SP-A and SP-B reflect tobacco-smoke exposure in asymptomatic subjects. Eur Respir J 2002, 20:1152-1161.

34. Nomori H, Horio H, Fuyuno G, Kobayashi R, Morinaga S, Suemasu K: Serum surfactant protein A levels in healthy individuals are increased in smokers. Lung 1998, 176:355-361.

35. Kida K, Oda H, Yamano Y, Kagawa J: Effects of cigarette smoking on the serum concentration of lung surfactant protein A (SP-A). Eur Respir J 1997, 10:2124-2126.

36. Behera D, Balamugesh T, Venkateswarlu D, Gupta A, Majumdar S: Serum surfactant protein-A levels in chronic bronchitis and its relation to smoking. Indian J Chest Dis Allied Sci 2005, 47:13-17.

37. Greene KE, King TE, Kuroki Y, Bucher-Bartelson B, Hunninghake GW, Newman LS, Nagae H, Mason RJ: Serum surfactant proteins-A and -D as biomarkers in idiopathic pulmonary fibrosis. Eur Respir J 2002, 19:439-446.

38. Vlachaki EM, Koutsopoulos AV, Tzanakis N, Neofytou E, Siganaki M, Drositis I, Moniakis A, Schiza S, Siafakas NM, Tzortzaki EG: Altered surfactant proteinA expression in type II pneumocytes in COPD. Chest 2010, 137:37-45.

39. Fujishima T, Takahashi H, Abe S: Cytokines and surfactant as a factor of onset and progression of COPD. Nippon Rinsho 1999, 57:1976-1981.
40. Floros J: Human surfactant protein A (SP-A) variants: why so many, why such a complexity? Swiss Med Wkly 2001, 131:87-90.

41. Tagaram HR, Wang G, Umstead TM, Mikerov AN, Thomas NJ, Graff GR, Hess JC, Thomassen MJ, Kavuru MS, Phelps DS, Floros J: Characterization of a human surfactant protein A1 (SP-A1) gene-specific antibody; SP-A1 content variation among individuals of varying age and pulmonary health. Am J Physiol Lung Cell Mol Physiol 2007, 292:L1052-L1063.

42. Guo X, Lin HM, Lin Z, Montano M, Sansores R, Wang G, DiAngelo S, Pardo A, Selman M, Floros J: Surfactant protein gene A, B, and D marker alleles in chronic obstructive pulmonary disease of a Mexican population. Eur Respir J 2001, 18:482-490.

43. More JM, Voelker DR, Silveira LJ, Edwards MG, Chan ED, Bowler RP: Smoking reduces surfactant protein $D$ and phospholipids in patients with and without chronic obstructive pulmonary disease. BMC Pulm Med 2010, 10:53.

44. Sims MW, Tal-Singer RM, Kierstein S, Musani Al, Beers MF, Panettieri RA, Haczku A: Chronic obstructive pulmonary disease and inhaled steroids alter surfactant protein D (SP-D) levels: a cross-sectional study. Respir Res 2008, 9:13

45. Lim S, Roche N, Oliver BG, Mattos W, Barnes PJ, Chung KF: Balance of matrix metalloprotease- 9 and tissue inhibitor of metalloprotease- 1 from alveolar macrophages in cigarette smokers. Regulation by interleukin-10. Am J Respir Crit Care Med 2000, 162:1355-1360.

46. Laitinen T, Hodgson U, Kupiainen H, Tammilehto L, Haahtela T, Kilpeläinen M, Lindqvist A, Kinnula VL: Real-world clinical data identifies gender-related profiles in chronic obstructive pulmonary disease. COPD 2009, 6:256-262.

\section{Pre-publication history}

The pre-publication history for this paper can be accessed here: http://www.biomedcentral.com/1471-2466/11/19/prepub

doi:10.1186/1471-2466-11-19

Cite this article as: llumets et al:: Ageing and smoking contribute to plasma surfactant proteins and protease imbalance with correlations to airway obstruction. BMC Pulmonary Medicine 2011 11:19.

\section{Submit your next manuscript to BioMed Central and take full advantage of:}

- Convenient online submission

- Thorough peer review

- No space constraints or color figure charges

- Immediate publication on acceptance

- Inclusion in PubMed, CAS, Scopus and Google Scholar

- Research which is freely available for redistribution

Submit your manuscript at www.biomedcentral.com/submit
Ciomed Central 